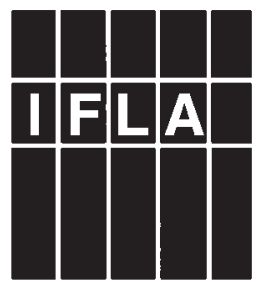


International Federation of Library Associations and Institutions

Fédération Internationale des Associations de Bibliothécaires et des Bibliothèques

Internationaler Verband der bibliothekarischen Vereine und Institutionen

Международная Федерация Библиотечных Ассоциаций и Учреждений

Federación Internacional de Asociaciones de Bibliotecarios y Bibliotecas

国际图书馆协会与机构联合会

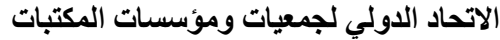

\section{About IFLA}

www.ifla.org

IFLA (The International Federation of Library Associations and Institutions) is the leading international body representing the interests of library and information services and their users. It is the global voice of the library and information profession.

IFLA provides information specialists throughout the world with a forum for exchanging ideas and promoting international cooperation, research, and development in all fields of library activity and information service. IFLA is one of the means through which libraries, information centres, and information professionals worldwide can formulate their goals, exert their influence as a group, protect their interests, and find solutions to global problems.

IFLA's aims, objectives, and professional programme can only be fulfilled with the cooperation and active involvement of its members and affiliates. Currently, approximately 1,600 associations, institutions and individuals, from widely divergent cultural backgrounds, are working together to further the goals of the Federation and to promote librarianship on a global level. Through its formal membership, IFLA directly or indirectly represents some 500,000 library and information professionals worldwide.

IFLA pursues its aims through a variety of channels, including the publication of a major journal, as well as guidelines, reports and monographs on a wide range of topics. IFLA organizes workshops and seminars around the world to enhance professional practice and increase awareness of the growing importance of libraries in the digital age. All this is done in collaboration with a number of other non-governmental organizations, funding bodies and international agencies such as UNESCO and WIPO. IFLANET, the Federation's website, is a prime source of information about IFLA, its policies and activities: www.ifla.org

Library and information professionals gather annually at the IFLA World Library and Information Congress, held in August each year in cities around the world.

IFLA was founded in Edinburgh, Scotland, in 1927 at an international conference of national library directors. IFLA was registered in the Netherlands in 1971. The Koninklijke Bibliotheek (Royal Library), the national library of the Netherlands, in The Hague, generously provides the facilities for our headquarters. Regional offices are located in Rio de Janeiro, Brazil; Pretoria, South Africa; and Singapore. 
IFLA Publications 136-137

\section{Global Library and Information Science}

A Textbook for Students and Educators

With Contributions from

Africa, Asia, Australia, New Zealand,

Europe, Latin America and the Carribean, the Middle East, and North America

Edited by

Ismail Abdullahi

K·G·Saur München 2009 


\section{IFLA Publications \\ edited by Sjoerd Koopman}

\section{Bibliographic information published by the Deutsche Nationalibliothek}

The Deutsche Nationalbibliothek lists this publication in the Deutsche Nationalbibliografie; detailed bibliographic data is available in the Internet at http://dnb.d-nb.de.

(2)

Printed on permanent paper

The paper used in this publication meets the minimum requirements of

American National Standard - Permanence of Paper

for Publications and Documents in Libraries and Archives

ANSI/NISO Z39.48-1992 (R1997)

(C) 2009 by International Federation of Library Associations

and Institutions, The Hague, The Netherlands

Alle Rechte vorbehalten / All Rights Strictly Reserved

K. G. Saur Verlag, München

An Imprint of Walter de Gruyter GmbH \& Co. KG

All rights reserved. No part of this publication may be reproduced, stored in a retrieval system of any nature, or transmitted, in any form or by any means, electronic, mechanical, photocopying, recording or otherwise, without the prior written permission of the publisher.

Printed in the Federal Republic of Germany by Strauss GmbH, Mörlenbach

ISBN 978-3-598-22042-5

ISSN 0344-6891 (IFLA Publications) 